\title{
Notes towards a semiotics of parasitism
}

\author{
Han-liang Chang \\ Dept. of Foreign Languages and Literatures, National Taiwan University \\ No. 1, Sec. 4, Roosevelt Road, Taipei, 106 Taiwan \\ e-mail: changhl@ccms.ntu.edu.tw
}

\begin{abstract}
The metaphor of parasites or parasitism has dominated literary critical discourse since the 1970s, prominent examples being Michel Serres in France and J. Hillis Miller in America. In their writings the relationship between text and paratext, literature and criticism, is often likened to that between host and parasite, and can be therefore deconstructed. Their writings, along with those by Derrida, Barthes, and Thom, seem to be suggesting the possibility of a semiotics of parasitism. Unfortunately, none of these writers has drawn enough on the biological foundation of parasitism. Curiously, even in biology, parasitism is already a metaphor through which the signified of an ecological phenomenon involving two organisms is expressed by the signifier of "[eating] food at another's [side] table". This paper will make some preliminary remarks on semiotics of parasitism, based on the notions of Umwelt (Jakob von Uexküll) and structural coupling (Maturana and Varela). It will look into the phenomenon of co-evolutionary process in community ecology. With reference to empirical history, the project will briefly survey the literary and medical praxis of the 17th century England where large number of creative writings referred to the phenomenon of parasitism, which was deeply embedded in religious practice (e.g., the Eucharist) and political life (e.g., the courtier ecology in monarchy) of the times. Finally, it will touch upon the possible 'parasitic' relationship between language and biology.
\end{abstract}

\section{Parasite: The word and the matter}

Despite its Greek etymology of $\pi \alpha \rho \alpha+\sigma \imath \tau o \varsigma$, meaning "beside + grain [food]" or by extension "one who eats at the table of another", the word parasite appears rather late in the European languages. It first appeared in the 16th century, traceable to Rabelais [1535] in French, and was recorded a few times in Shakespeare's plays. In his 
Timon of Athens [1607] Shakespeare has the hero inveigh his 'MouthFriends' as 'most [...] detested Parasites".

Live loathed and long,

Most smiling, smooth, detested parasites,

Courteous destroyers, affable wolves, meek bears,

You fools of fortune, trencher-friends, time's flies,

Cap and knee slaves, vapours, and minute-jacks!

Of man and beast the infinite malady

Crust you quite o'er!

(Shakespeare, Timon of Athens [1607] III, vi, 53-59)

The same year 1607 saw Ben Jonson's explicit reference to a character as parasite. In his Volpone the hero addresses his servant: "Hold thee, Mosca, / Take of my hand; thou strik'st on truth, in all: / And they are enuious, terme thee Parasite" (I, i, 1-3), thus suggesting the current folk wisdom that the fly was a parasite. The popular use of the word was not, however, enough to give rise to the scientific knowledge devoted to the study of these strange creatures. Notwithstanding the invention of the microscope in the 17 th century, the discipline of parasitology appeared much later, dating probably in the mid 19th century with the pioneering work of the Belgian biolgist Pierre-Joseph van Beneden (1809-1894), who unraveled the life history of tapeworms and other groups.

\section{From worm to flea: Parasites in 17th-century texts}

However, the belated register of the word parasite in French and English and the medical science dealing with it by no means suggests that the biological concept and its various implications had to wait until the linguistic coinage and medical institutionalization. A much older word, probably of Scandinavian origin, and extremely popular in Renaissance texts is worm. It is a favourite word of Shakespeare's although it is used in several senses, some of which not necessarily related to parasitism. Where shall we start except to pay homage to our host? So we start with Hamlet, the Prince of Denmark. Having just slain Polonius, by accident per chance, Hamlet is confronted with his uncle Claudius. 


\begin{tabular}{|c|c|}
\hline LAUDIUS & Now, Hamlet, where's Polonius? \\
\hline IAMLET & At supper. \\
\hline LAUDIUS & At supper! where? \\
\hline А & $\begin{array}{l}\text { Not where he eats, but where he is eaten: a certain } \\
\text { convocation of politic worms are e'en at him. Your } \\
\text { worm is your only emperor for diet: we fat all } \\
\text { creatures else to fat us, and we fat ourselves for } \\
\text { maggots: your fat king and your lean beggar is but } \\
\text { variable service, two dishes, but to one table: } \\
\text { that's the end. }\end{array}$ \\
\hline LAUDIUS & Alas, alas! \\
\hline IAMLET & $\begin{array}{l}\text { A man may fish with the worm that hath eat of a } \\
\text { king, and eat of the fish that hath fed of that worm. }\end{array}$ \\
\hline LAUDIUS & What dost you mean by this? \\
\hline AMIFT & $\begin{array}{l}\text { Nothing but to show you how a king may go a } \\
\text { progress through the guts of a beggar. } \\
\text { re, Hamlet }[1603] \text { IV, iii, } 24-30 \text {; my emphasis) }\end{array}$ \\
\hline
\end{tabular}

This is not the occasion to interpret once more the well-known passage. What interests me is the life cycle and food chain which Hamlet evokes. The cycle involves three groups, (1) human (e.g., beggar and king), (2) fish, (3) worm, all of which enter into a predator versus prey chain relationship. Now this only parallels the life cycle of a parasite because of the ambiguity of the word "worm" in Shakespeare. Among other things, the word had the following senses in Shakespeare's time: (1) the earthworm or Lumbricus terrestris, (2) the maggot, and (3) the parasite, and the first two were often confused, hence the popular notion that earthworms feed on corpses, which incidentally is true.

If the worm is the earthworm, then there is implicit parasitism involving the host of Lumbricus terrestris and the yet unidentified parasite of Metastrongylus elongatus, which serves in turn as the intermediate host of pig flu virus strain that was to claim twenty million lives in the early 20th century. An immediate parallel is the recent outbreak of the epidemic SARS in East Asia caused by a new form of coronavirus. Thus the life cycle described by Hamlet can be expanded to include microscopic and ultramicroscopic bacteria and viruses not foreseeable to the prince despite his poetic vision. To account more adequately for this expanded life cycle, the melancholy Danish crown prince would have had to seek inspiration from the as yet non-existent parasitology, bacteriology (1880s), and virology (1930s), all of which deal respectively with the phenomenon of organismic associations. Needless to say, even this expanded version 
cannot hope to exhaust everything because of the imprecise nomenclature of fish and worm, and the possibility that many taxa of worms and fish are involved, granted there are more than 1,800 species of terrestrial worms known to us, and thousands of microorganisms they live on. However, lest we be carried away, let us pause here and go back to the strange worm, which was unfortunately confused with the maggot.

We are aware the ill-defined worm, when mistaken for the maggot, is in fact the larva of Diptera, such as the true fly. About half the fly species have larvae known as maggots. Most of them feed on decaying organic matter, including the dead bodies of kings and beggars, but again there are wide differences in the food preferences of different flies. Eight "waves" of maggots have been distinguished; each wave attacks dead animals in a strict sequence as decay progresses from the newly dead corpse through rigor and putrefaction to mummification. What do maggots suggest then? Why, they suggest the life cycle of Diptera, in particular, Cyclorrhapha, which breed in dead animals, so as to complicate the process outlined by Hamlet.

We are yet to meet with parasites textualised. As I said in the beginning, the Renaissance texts are not short of them, especially given its monarch-dependent courtier culture. Even a definition from a parasitology textbook would introduce the parasite as a "person who received free meals from a rich patron, in return for amusing, impudent, and flattering conversation; in other words, a sycophant" (Brooks, McLennan, 1993: 2). The best example of this kind of mutualism is perhaps Ben Jonson's Mosca, meaning fly, in his Volpone. But to the extent that a parasite feeds on and eventually kills his host, one thinks of Bosola in John Webster's Duchess of Malfi (performed 1613, published 1623) who gives a vivid ecological picture of parasitism.

BOSOLA: He and his brother are like plum trees, that grow crooked over standing pools, they are rich, and o'erladen with fruit, but none but crows, pies, and caterpillars feed on them. Could I be one of their flatt'ring panders, I would hang on their ears like a horse-leech, till I were full, and then drop off.

(Webster, Duchess of Malfi [1623] I, i, 38)

This text gives a better picture of the interaction between living systems on the one hand, and that between living systems and their environments on the other. The living systems include (1) plum trees, 
(2) crows, magpies, and caterpillars, (3) horse-leech, (4) human "flatt'ring panders" (i.e., servants to the Duke); and the environments that provide location for the construction of their Umwelten are (1) standing pools, (2) fruit, (3) [horse] ears, (4) Dukedom (or the Duke on whom his panders live on). The main function of the environments, as Jakob von Uexküll would say, is providing food-circle. It is interesting to note living systems and environments are reciprocal in 3 and 4, i.e., the environments are living systems in themselves. Much as the horse-leech lives on [the blood from] horse ears, sycophants live on [the provisions from] the Duke. That is where parasitism occurs both in nature and in culture. The only reservation one may have is a relatively minor one: i.e., whether the horse-leech (Haemopis sanguisuga of phylum Annelida) is a parasite, a blood predator, or even just a predator of smaller invertebrate animals, though the playwright obviously takes it to be, or mistakes it for, a parasite. ${ }^{1}$

Such courtier-parasites abound in Shakespeare and other Elizabethan and Jacobean writers. Even in Hamlet we have a host of them: Polonius, Osiric, Rosencranz and Gildenstern. From Jacobean theatrum parasitum, we move to poetry. None other is better known than John Donne's (1572-1631) "The Flea," published posthumously in 1633 .

1 According to one interpretation (uk.rec.gardening web-ring), none of the three kinds of leech found in the U. K. today is harmful to humans. Webster's knowledge of horse-leech may have been mediated by the Biblical allusion in Proverbs, which is an isolated instance. But obviously the phrase horse-leech had a referent in Webster's times, and therefore had a historical basis; otherwise, the translator would not have rendered 'alukah into horse-leech. The leech referred to in the Book of Proverbs 30: 15, 'alukah may not have been found in England, but its behaviour must have caught Wester's attention. Or more likely, there was a species of leech in Jacobean England, with which the Biblical worm was identified. The following description from Easton's Bible dictionary is helpful to our understanding of the passage: "There are various species in the marshes and pools of Palestine. That here referred to, the Hoemopis, is remarkable for the coarseness of its bite, and is therefore not used for medical purposes. They are spoken of in the East with feelings of aversion and horror, because of their propensity to fasten on the tongue and nostrils of horses when they come to drink out of the pools. The medicinal leech (Hirudo medicinalis), besides other species of leeches, is common in the waters of Syria." We are not sure if parasitic leeches were existent in Webster's England, but the medicinal leech had been widely used since the 17th century. The book I consulted in the Museum of Natural History in London is Johnson (1816). 
MARK but this flea, and mark in this, How little that which thou deniest me is; It suck'd me first, and now sucks thee, And in this flea our two bloods mingled be.

Thou know'st that this cannot be said A sin, nor shame, nor loss of maidenhead;

Yet this enjoys before it woo, And pamper'd swells with one blood made of two; And this, alas! is more than we would do.

O stay, three lives in one flea spare,

Where we almost, yea, more than married are.

This flea is you and I, and this

Our marriage bed, and marriage temple is.

Though parents grudge, and you, we're met, And cloister'd in these living walls of jet. Though use make you apt to kill me, Let not to that self-murder added be, And sacrilege, three sins in killing three.

Cruel and sudden, hast thou since Purpled thy nail in blood of innocence?

Wherein could this flea guilty be, Except in that drop which it suck'd from thee? Yet thou triumph'st, and say'st that thou Find'st not thyself nor me the weaker now.

'Tis true; then learn how false fears be; Just so much honour, when thou yield'st to me, Will waste, as this flea's death took life from thee.

(John Donne, "The Flea" [1633]; my emphasis)

The poet describes the relationship between flea and human, in this case, the first-person addresser and the second-person addressee as lovers: "It suck'd me first, and now sucks thee, / And in this flea our two bloods mingled be". The result of the flea bite is "pamper'd swells with one blood made of two". Despite its accuracy in observation, this kind of poetic extravagance may sound strange to an ear unused to lyricism, but it would have made sense to a modern day parasitologist.

First of all, he may have questioned the systematic issue of the flea as a real ectoparasite or a blood predator. Then he would be attracted to the interaction between parasite and host, e.g., how the one feeds on the other, using the other to construct its Umwelt primarily as food rather than as habitat, how as a result, the host becomes "weaker", as 
described later in line 24. This would lead him to account for the biochemical metabolism of the two parties involved. Finally, we know that the flea preys on more than one host, indeed jumps from one species to another, say, from cats to humans, ${ }^{2}$ and that the flea may enter into competition with other parasitic phyla, orders, and species. Such facts would shift the biologist's or, more precisely, epidemiologist's, attention from individual organism to species and to population, in both parasite and host, thus pointing to the socio-medical context of parasitism (in relation to such human diseases as plague and typhus) in the 17th-century England. ${ }^{3}$ Further inquiries would return us to the same issue of life cycle and development of the flea, from egg to larva, from larva to pupa, and from pupa to adult, the latter finally finding a host in Donne's speaker and then in his lover, and, not purely out of coincidence, reaching maturity together with the human sexual consummation to which the poet devoutly aspires (lines 27-29).

What do the texts of Hamlet and "The Flea" reveal? A matter-offact position may observe that neither Shakespeare nor Donne was

2 Again, this is paralleled by the life-cycle of the SARS coronavirus. On Saturday, 24th May, 2003, the Associated Press released a news in London: "Researchers from the University of Hong Kong examined 25 animals belonging to eight species in a live animal market in southern China that supplies restaurants in Guangdong province, where the SARS outbreak is believed to have started. Six of the animals tested were masked palm civets, which look like long-nosed cats but are related to the mongoose. All the civets, which came from several different owners and appeared healthy, tested positive for a SARS-like virus, said Dr. Klaus Stohr, WHO's chief SARS virologist. One raccoon dog - a member of the dog family native to eastern Asia - was tested and found to have the virus in its feces."

Another recent finding is the virus strains that cause AIDS. The AP reported on 14th June 2003: "After analyzing the DNA make-up of the simian immunodeficiency virus (SIV) in African monkeys they [a group of scientists in America and France] found the red-capped mangabeys and spot-nosed guenons carried the strains"; and then "the virus was passed onto chimpanzees when they ate infected monkey meat," and finally passed on to humans probably before 1930s.

3 I have consulted the following information in the Museum of London: Regulations on Public Health (1623), Book of Regulations (1588), Mortality Broadsheet (London: John Winder, 1604?). The last one has this record: "Nov. $1602-$ Nov. 1603. The plague struck severely in 1603 , nearly 37,000 deaths were attributed to it that year, out of 42,700 deaths recorded." The record clearly suggests that the sick world of Denmark in Shakespeare's Hamlet has an immediate topic reference. 
aware of the compound microscopes constructed by the Dutch sometime between 1590 and 1608, not to mention the more refined form developed by Robert Hooke (1635-1703) in England long after the poets' death. ${ }^{4}$ A traditional but now naïve view would insist on the distinction between literary discourse and biological discourse, a distinction that endows the poet with a license to let fly of his imagination. From this fictitious distinction one may develop accordingly a literary semiotics and a biological semiotics, as if the latter could be immuned from the contamination of language. This, of course, is to miss the encroachment of rhetoric on biology and the fact that even parasitology as a positive science is encoded in language in the first place. See, for instance, the trendy title of a 1993 book on parasitism: Parascript: Parasites and the Language of Evolution, where the authors call attention to the many "myths, metaphors, and misconceptions" (Brooks, McLennan 1993: ix) about parasites and their evolution, but believe, as did their predecessor Harold W. Manter, that the parasites themselves are capable of forming a meaningful language called parascript [Sic.] that tells of their lives (Brooks, McLennan 1993: 21).

\section{The parasite metaphor in 20th-century critical discourse}

The now banal-sounding witticism in "parascript" takes us to mid 20th-century writings. The word is etymologically dubious, but would not make a strange bedfellow with "paracriticism", coined by the American literary critic Ihab Hassan (1975), "paratext" proposed by the French narratologist Gérard Genette (1997), and other similar paradox-ladden wordplays that have inflicted literary criticism over the past half-century. As early as 1955, J. L. Austin, founder of speech-act philosophy, already described some extreme cases of performative use of language, such as on the stage (e.g., Hamlet) or in a poem (e.g., "The Flea"), as "parasitic upon its [language's] normal use" (Austin 1975: 22). And it was Jacques Derrida who, in his persistent critique on the presence and transparency of speech communi-

4 Two microscopes I saw in the Museum of Science in London were developed by Anthony van Leeuwenhoek (1632-1723), [Museum of Science London, Inventory No. A500644. Leeuwenhoek Microscope. Dutch, c. 1673] and Johan van Musschenbroek (1660-1707) [Musschenbroek Microscope, Dutch, 1686. Museum of Science London, Inventory No.A137247]. 
cation, launches a deconstruction (i.e., reversal and displacement) of the host/parasite relationship in language use, including speech and writing (1977 [Fr. 1971]).

We note Derrida's use of parasitism, like Austin before him, is a metaphor borrowed from biology, but neither of them questioned the force and limit of the metaphor. More often than not, once when the critic has received the message or the tenor, s/he tends to ignore the vehicle in which the tenor is carried. Derrida's comment on Austin has actually levelled a metacommentary on second-order observation: What kind of metaphorical structure is retained in the expression of parasitism when it is used not as a metaphor, but as a constative statement, as Austin would say, about "real" parasites and their hosts? Needless to say, we cannot pause and feel gratified with the simplistic

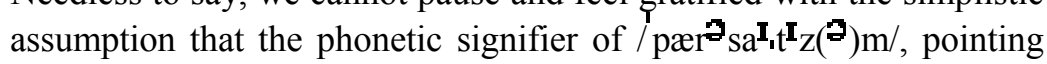
to the semantic signified of [parasitism], amounts to the vehicle/tenor relationship of metaphor. By so doing, either we get into a circular argument or we end up in semiosic regressus ad infinitum. Having said this, it is interesting to rethink the semantic felicity of the coinage parascript where the parasitologist finds shelter in another metaphor borrowed from language, i.e., from grammatology, to encode parasitism. The brainstorms to be raised by the encounter of advocates of parasitism and parascript are yet to be measured.

With this metaphor we shall mention two critics who have made the metaphor of parasitism famous and popular. I refer to J. Hillis Miller, a boa deconstructor at Yale in the late 1970s ("The Critic as Host" 1979 [1977]) to 1980s, and Michel Serres, the science historian turned literary critic at Sorbonne (Le Parasite 1980). ${ }^{5}$ Miller's article was first published in Critical Inquiry as a rejoinder to the prolonged debate on cultural pluralism and interpretation, which involved major literary critics on both left and right wings, including M. H. Abrams, Wayne C. Booth, and others.

5 Michel Serres may not have read Miller's essay because his book-length study of parasitism, to date the only one of its kind, was published immediately afterwards as a sequel to his multi-volumed Hermes. Serres's definition of parasite is rather liberal. In addition to biology (and literature, mainly 17th-century French), his parasitism as a grand récit or master-code incorporates the insight of thermodynamics, cybernetics, and linguistics. Interestingly, in French (as well as English) there is the linguistic phenomenon of phonological parasitism, e.g., a sound inserted in the middle of a word. It is therefore regarded as a noise with which Serres takes much pleasure in playing. 
The debate concerns the authority of textual interpretation. A traditionalist like Abrams believes that there is an obvious and univocal reading of a work, and other readings, such as deconstructive, are but "parasitical". In a strategy resembling Derrida's critique of Austin cited above, Miller launches an attack by dismantling the fictitious opposition of host and parasite. He resorts to etymology and dress rehearses the Derridian dissemination of lexical signs, in particular, the para- family, and host and guest, to deconstruct the differentiation of host and parasite. One of the conclusions is neither the obvious and univocal reading nor the deconstructive reading can claim the status of host because both are parasitic on the poem which, in turn, is parasitic on an infinite number of other poems and texts before it. Throughout the essay, Miller engages some binary oppositions commonly held to be true, such as host/alien, inside/outside, and he plays on the logic of the Greek prefix para which gives rise to each word its double:

Each word in itself becomes divided by the strange logic of the 'para,' membrane which divides inside from outside and yet joins them in a hymeneal bond, or which allows an osmotic mixing, making the stranger friend, the distant near, the Unheimlich Heimlich, the homely homey, without, for all its closeness and similarity, ceasing to be strange, distant, and dissimilar. (Miller 1979: 221)

The linguistic logic certainly applies to many words and the notions they articulate, such as text/paratext, criticism/paracriticism, etc. One of the dangers of this kind of lexical extravagance is that it will carry us away. For example, among the words given by Miller, the para- in parachute, parasol and parapluie is from the Italian root, meaning "ward off," rather than the Greek root in paragon and paradox and parasite (Miller 1979: 219-220). Another danger is the irreversibility of the generative-disseminative rule. For instance, one can certainly retrieve text from paratext, but one cannot do the same from parasitos to sitos. Why? Because the word text generates paratext not only through the mechanism of syllabic and morphemic combination, but also through semantic reduplication, thanks to the mysterious selfreflexive prefix para. That's why we have paralinguistics and parapsychology, both in name and in matter, but not paraparasitology. Of course we could, but the condition is that we solve the problem of

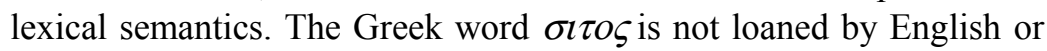
French and as such does not have a life of its own. As a morpheme, it 
is brought to life, so to speak, in English by another Greek morpheme $\pi \alpha \rho \alpha$. If there were no morphemes (or semes) para and sitos, there would be no parasitos. One could argue that if there were no text, there would be no paratext, but the lexical rules are completely different because text can serve both as morpheme and as word.

What about the biological parasite? How successful is it as a metaphor? What kind of economy is involved in this "curious system of thought, or of language, or of social organization?" (Miller 1979: 220). As far as literature is concerned, Miller believes the relationship of parasitism is triangular rather than binary. That is, the poem plays host and both the rightist and leftist readings are parasitic on the host poem.

Both readings, the 'univocal' one and the 'deconstructive' one, are fellow guests 'beside the grain,' host and guest, host and host, host and parasite, parasite and parasite. The relation is a triangle, not a polar opposition. There is always a third to whom the two are related, something before them or between them, which they divide, consume, or exchange, across which they meet. (Miller 1979: 224)

This is very well said indeed. And it goes perfectly well with the relation between fellow-parasitic interpreters. But then the relation cannot be a triangular one because insofar as they are co-parasites, their relationship to the host is still dyadic rather than triadic. It's not Peircean because of the lack of a Thirdness. The host cannot be a Third, as Miller suggests, but may be a First, which the parasite as Second invades. The host and the parasite have to interact on the same existential or ecological or, more precisely, semiotic level to ensure their interaction, i.e., the host and/or parasite as reciprocal sign (representamen) and object. What about the Third? The Third is probably a conceptual category on a higher level, whether the name is mutualism, commensalisms, symbiosis, parasitism, or even Umwelt, which serves to define the host/parasite relationship.

With a stroke of genius, Miller gives an example of virus and that is where he is nearest to the life science. We have refrained from using biology because of the dubious status of the cell-less virus.

One of the most frightening versions of the parasite as invading host is the virus. In this case, the parasite is an alien who has not simply the ability to invade a domestic enclosure, consume the food of the family, and kill the host, but the strange capacity, in doing all that, to turn the host into multitudinous proliferating replications of itself. The virus is at the easy border between life 
and death. It challenges that opposition, since, for example, it does not 'eat,' but only reproduces. It is as much a crystal or a component in a crystal as it is an organism. The genetic pattern of the virus is so coded that it can enter a host cell and violently reprogram all the genetic material in that cell, turning the cell into a little factory for manufacturing copies of itself, so destroying it. (Miller 1979: 222)

The invasion of virus that breaks into the membrane of cell, not to eat, but to copy and reproduce has rich biosemiotic implications which needs further development.

Unfortunately, instead of tilling this fertile ground, Miller, in the final part of his essay, which is an analysis of Shelley's Triumph of Life, focuses on plant parasitism and thus loses the impetus. At any rate, botanical parasitism always looks less ugly than animal parasitism, especially endoparasitism. To be fair to Miller, and to render justice to his service, the American critic has rightly dismantled the opposition traditionally accorded to parasite and host, and demonstrated that their relationship can be displaced, and has identified, instead, the two parties' reciprocal obligations in food-giving and food-receiving (Miller 1979: 225). But this is to miss an important element in parasitic relationship. Miller is in fact discussing biological mutualism or symbiosis rather than parasitism because the latter involves the host's disease and death, putting an end to semiosis. The irony is that Miller's recourse to the metaphor of parasitism is useful for the deconstruction of cultural binarism, but not useful for biological parasitism, which is a matter of life and death.

\section{Two semiotic themes: Life cycle and host/parasite interaction}

It is to the late Jakob von Uexküll that we owe a debt of gratitude for the genesis of meaning in animal life. Although Uexküll did not dwell on the phenomenon of parasitism, the comprehensive scope of his ecology anticipated many subsequent developments. There are random references to parasitism in his English translations. In Theoretical Biology (1926), the author discusses the food-circle and enemy-circle of living organisms, and observes how the malaria parasite takes altogether unlike hosts as food-circle. "This minute unicellular animal has the power not only to adapt itself to the totally different tissuejuices of the mosquito and of man, but is able to find its way about in 
the anatomy of these two very unlike hosts" (Uexküll 1926: 165). On another occasion, he mentions the parasites' function of inneradjustment: "In parasites we find prehensile feet which are exactly inter-adjusted with the tissues of the hosts furnishing them with a medium" (Uexküll 1926: 162). This, in parasitology, is called anchorage, one function of biomechanics that helps the parasite to construct its habitat in the host's body. Put in semiotic terms, this biophysical indexical sign points to a higher order of symbolic sign, i.e., the structural interface of the parasite/host Umwelt.

The interaction of the animal and its environment, specifically, the interaction of its world of sense and its world of action, is defined by a number of function-circles. The chain composed by indicator, receptor, and effector on the one hand, and the surrounding world (world as sensed plus world of action) and inner world on the other, suggests a self-contained Umwelt. For all its pretension to autopoeisis, the Umwelt of an animal is not a closure and is constantly engaged by stimuli and actions from without. Such actions can be incited from different sources and can assume different forms, predation being an obvious one. As Uexküll says, "If this [function] circle is interrupted at any point whatsoever, the existence of the animal is imperilled" (Uexküll 1926: 127).

Other than predation, parasitism offers an extremely fascinating case because it is in here that we see the overlapping and interface of two Umwelten, that of the parasite and that of the host. From a casual observer's point of view, the parasite and the host, so long as they reside together, can be said to share one world from which is constructed two interlocked Umwelten. The host provides the parasite with food and habitat at the expense of its own life, and the parasite constructs the food and habitat sectors of its function-circle, temporarily or permanently, in another's body. In reaction to this invasion of the parasite, the host tries to protect itself by mounting various defense mechanisms, such as immunity, mediated either by antibodies or by cells, meanwhile the parasite tries hard to evade the host's immunity, so as to get the upper hand of its victim. An example of this exchange is the phenomenon of molecular mimicry, which shows the parasite's ability to produce surface antigens that are similar to those of its host (Damian 1964, qouted in Ahmadjian, Paracer, 1986: 148). It can be said that a measure of a parasite's success is its ability to evade the response from the host, which is aimed at the parasite's elimination. 
Thus the ecology of parasitism is based on and represented by a unique situation of double Umwelt, a Derridian différance, so to speak, made possible by the temporality of colonization during the parasite's life cycle, as well as the interfacial space in which occurs the structural coupling of two living systems. How could the semiotician resist the temptation to decode (as he encodes) this marvellous phenomenon? Maturana and Varela would term the phenomenon "mutual ontogenic structural coupling" when these two living systems interact recursively, the host becoming a medium for the parasite's realization of its autopoiesis, while the parasite laying constraints on, indeed threatening, the host's chances of autopoiesis. Although the notion of autopoiesis seems incompatible with parasitism, structural coupling can be useful in representing, as a Peircian symbolic sign, the life process of a parasite, be it viral, bacterial, protozoan, platyhelminth, nematodian, or arthropodan.

We are told that an animal's life is an autopoietic cycle, so is its Umwelt. That cycle becomes all the more complex when the animal is a parasite because on the one hand its life cycle consists of disrupted parasitic, meta-parasitic, and free-living stages, and on the other, it gets involved with the life cycle of another life, or several other lives, which also tries to maintain its autopoiesis. Maturana and Varela (1987: 88) discuss what may happen to two autopoietic cellular unities in symbiosis. Structural coupling through recurrent interactions may drift in two directions. One direction moves towards the inclusion of boundaries; the other towards metacellularity where participating cells can preserve their individual limits but a new coherence is formed. Through structural coupling, the ontogenic process of life gives way to the phylogenic coevolutionary process of both living systems.

We should be aware that parascript, Umwelt, autopoiesis, structural coupling can be all regarded as Peircian interpretants in linguistic constructs to "represent" natural phenomena which some assume to be transparent. But the truth is that these natural phenomena were already encoded in language when first made available and known to us. Naming and taxonomy are good examples of language's initial encoding of nature, an act which serves as the foundation for secondorder scientific studies. The quotation from Hamlet in Section 1 above clearly shows the clash of naming systems. If so, these linguistic tertiary symbolic signs, such as Umwelt and structural coupling, are but instances of metalanguage whose job it is to model and articulate the object-language of life. Therefore, very little distinction can be 
made between nature and culture, or for that matter, the nature and culture of parasitism.

Instead of pushing the arguments of Umwelt and structural coupling further to account for the parasite/host relationship, I would like to reinstate an old semiotic model of value exchange developed from A. J. Greimas's structural semantics $(1983$; 1987). For the parasite, the value consists of two elements, nutrition and habitat. If we retain Uexküll's preferred nominal for the living organism as subject rather than object (Uexküll 1926: 126), then the values it "desires", out of biological instinct, such as medium and food, serve as its object. This subject-seeking-object process then forms an elementary syntagmata in signification, comparable to Uexküll's interaction of world as sensed by a subject and its world of action. This subjectobject relation is coupled with another sender-receiver relation, thus constituting the communicative-performative syntagm of living organisms.

The exchange of value may first seem to be unilateral in that the host serves only as sender (expéditeur) and the parasite receiver (destinataire); but one could expand the realm of value to include other information-contents or messages, such as immunity, then the communication becomes bilateral or reciprocal. In fact, the relationship of sender and receiver can be reversed, depending on the contents of information emitted from the sender, be it food-resource or survival threat. This act of communication takes place in the shared Umwelt of the two subjects, or in the interfacial space of two Umwelten, and is performed by two actants in a reciprocal operation. To paraphrase Greimas, the doing of Subject 1 (Receiver) constitutes the performance component, while the doing of Subject 2 (Sender) constitutes the "retribution or sanction" component, either positive or negative (Greimas, Courtés 1979: 110).

In the world shared by parasite and host, insofar as the host sends the message to the parasite like an invitation to the Eucharist, the receiver will unlikely turn down the offer. See what the 17th-century poet George Herbert (1593-1633) has to say about this spiritual parasitism. 
Love bade me welcome, yet my soul drew back,

Guilty of dust and sin.

But quick-ey'd Love, observing me grow slack

From my first entrance in,

Drew nearer to me, sweetly questioning

If I lack'd anything.

"A guest," I answer'd, "worthy to be here";

Love said, "You shall be he."

"I, the unkind, the ungrateful? ah my dear,

I cannot look on thee."

Love took my hand and smiling did reply,

"Who made the eyes but I?"

"Truth, Lord, but I have marr'd them; let my shame

Go where it doth deserve."

"And know you not," says Love, "who bore the blame?"

"My dear, then I will serve."

"You must sit down," says Love, "and taste my meat."

So I did sit and eat.

(Herbert, "Love", III [1633])

Michel Serres unravels the myth behind the ritual of daily greetings in Greece: "П $\alpha \rho \alpha \kappa \alpha \lambda \omega$ "[By your grace!] "Ev $\chi \alpha \rho \imath \sigma \tau \omega$ !" [Thanks (for the Euchrist)!] $(1982,46)$ Once approaching or in the host body, the parasite sends a message, signaling invasion, then the host receives it and takes arms against it. This communicative-performative syntagmata not only accounts for the parasite/host interaction, but from a macroscopic perspective, with the departure and return motifs characteristic of journey narratives, defines the life cycle of a parasite. What emerges is a mysterious $U r$-parasitic narrative (and narratology), manifesting itself under varied disguises in the Umwelten of parasites, in nature as well as in the cultural texts of Hamlet, The Duchess of Malfi, and "The Flea". 6

This paper was presented at the Third Gathering of Biosemiotics in Copenhagen, 11-14 July 2003. 


\section{References}

Ahmadjian, Vernon; Paracer, Surindar 1986. Symbiosis: An Introduction to Biological Associations. Hanover: University Press of New England.

Austin, John L. 1975. How To Do Things with Words. (Urmson, J. O.; Sbisà, Marina, eds.) 2nd ed. Cambridge: Harvard University Press.

Brooks, Daniel R.; McLennan, Deborah A. 1993. Parascript: Parasites and the Language of Evolution. Washington: Smithsonian Institution Press.

Chappell, Leslie H. 1979. Physiology of Parasites. New York: John Wiley \& Sons.

Culpeper, Nicholas 1671. Semeiotica Uranica, or, An Astrological Judgiment of Diseases.

Damian, Raymond T. 1964. Molecular mimicry: Antigen sharing by parasite and its host and its consequences. The American Naturalist 98: 129-149.

Derrida, Jacques 1977 [1971]. Signature even context. [Weber, Samuel, trans.] Glyph: Johns Hopkins Textual Studies 1: 172-197.

Donne, John 1932. Complete Poetry and Selected Prose. (Hayward, John, ed.). London: The Nonesuch Press.

Esch, Gerald W.; Fernández, Jacqueline C. 1993. A Functional Biology of Parasitism: Ecological and Evolutionary Implications. London: Chapman \& Hill.

Greimas, Algirdas-Juilen 1983. Structural Semantics: An Attempt at a Method. (McDowell, Daniele; Schleifer, Ronald; Velie, Alan, trans.) Lincoln: University of Nebraska Press.

- 1987. On Meaning: Selected Writings in Semiotic Theory. (Perron, Paul J.; Collins, Frank H., trans.) Minneapolis: University of Minnesota Press.

Greimas, Algirdas-Julien; Courtés, Joseph 1982. Semiotics and Language: An Analytical Dictionary. (Crist, Larry et al., trans.) Bloomington: Indiana University Press.

Herbert, George 1983. The Complete Works of George Herbert. (Grosart, Alexander B., ed.). 3 vols. New York: AMS Press.

Hoffmeyer, Jesper 1997. Biosemiotics: Towards a new synthesis in biology. $S$ : European Journal for Semiotic Studies 9(2): 335-376.

Johnson, James Rawlins 1861. A Treatise on the Medicinal Leech, including its Medical and Natural History, with a Description of the Anatomical Structure, also remarks upon the Diseases, Preservation and Management of Leeches. London: Longman.

Jonson, Ben 1981. The Complete Plays of Ben Jonson. (Wilkes, G. A., ed.). 4 vols. Oxford: Clarendon Press.

Maturana, Humberto R.; Varela, Francisco J. 1992. The Tree of Knowledge: The Biological Roots of Human Understanding. (Paolucci, Robert, trans.) Rev. ed. Boston: Shambhala.

Miller, J. Hillis 1979. The critic as host. In: Bloom, Harold; Man, Paul de; Derrida, Jacques; Hartman, Geoffrey; Miller, J. Hillis 1979, Deconstruction and Criticism. New York: Continuum, 217-253. 
Noble, Elmer R.; Noble, Glenn A. 1964. Parasitology: The Biology of Animal Parasites. 2nd ed. Philadelphia: Lea \& Febiger.

Read, Clark P. 1972. Animal Parasitism. Englewood Cliffs: Prentice-Hall.

Serres, Michel 1982. The Parasite. (Schehr, Lawrence R., trans.) Baltimore: The Johns Hopkins University Press.

Shakespeare, William 1998. The Arden Shakespeare Complete Works. (Proudfort, Richard et al., eds.) Walton-on-Thames: Thomas Nelson.

Smith, David Cecil; Douglas, A. E. 1987. The Biology of Symbiosis. London: Edward Arnold.

Uexküll, Jakob von 1926. Theoretical Biology. (Mackinnon, D. L., trans.) London: Kegan Paul, Trench, Trubner.

Uexküll, Thure von 1982. Introduction: Meaning and science in Jakob von Uexküll's concept of biology. Semiotica 42(1): 1-24.

Ulmer, Gregory 1989. Teletheory: Grammatology in the Age of Video. New York: Routledge.

Webster, John 1927. The Complete Works of John Webster. (Lucas, F. L., ed.) 4 vols. London: Chatto \& Windus.

Whitfield, Philip J. 1979. The Biology of Parasitism: An Introduction to the Study of Associating Organisms. London: Edward Arnold.

Wilson, R. Alan 1979. An Introduction to Parasitology. 2nd ed. London: Edward Arnold.

\section{К семиотике паразитизма}

Метафора паразитов или паразитизма доминировала в литературнокритическом дискурсе начиная с 1970-х годов (наиболее известны Мишель Серр во Франции и Дж. Хиллис Миллер в Америке). В их работах соотношение между текстом и паратекстом, литературой и ее анализом, интерпретацией и критикой часто связывается с отношением между питающим организмом и паразитом, поэтому может быть деконструировано. Эти работы, наряду с трудами Деррида, Барта и Тома, наводят на мысль о возможности создания семиотики паразитизма. К сожалению, никто из этих авторов не углубляется в биологические основы паразитизма. Странно, что даже в биологии паразитизм трактуется как метафора, где означаемое экологического феномена, содержащего два организма, выражается означающим “[поедание] пищи с чужого стола”. В данной статье дается несколько предварительных замечаний по поводу семиотики паразитизма, основывающейся на понятии умвельта Якоба фон Юкскюлла и понятии структурного сцепления Матураны и Варелы, а также подчеркивая феномен коэволюционного процесса в аспекте экологии сообществ. Что касается эмпирической истории, мы даем краткий обзор литературных и медицинских примеров из истории Англии 17 
века, где большое число произведений упоминают паразитизм, что было глубоко укорено в религиозной практике (напр., евхаристия) и политической жизни (напр., отношение двора и монарха) этого времени. Наконец, намечаются возможности “паразитической” связи между языком и биологией.

\section{Parasitismi semiootikast}

Parasiitide või parasitismi metafoor valitses kirjanduskriitilist diskursust alates 1970ndatest aastatest Tuntumad on Michel Serres Prantsusmaalt ja J. Hillis Miller Ameerikast, kelle töödes seostatakse teksti ja parateksti, kirjanduse ja selle analüüsi, interpretatsiooni ja kriitika vaheline suhe tihti suhtega toituva organismi ja parasiidi vahel, võimaldades seega seda suhet dekonstrueerida. Need tööd, koos Derrida, Barthes'i ja Thomi omadega viivad mõttele parasitismi semiootika loomise võimalikkusest. Kahjuks ei süvene ükski neist autoreist parasitismi bioloogilistesse alustesse. Samas on kummaline, et isegi bioloogias tõlgendatakse parasitismi sageli kui metafoori, kus kaheorganismilise ökoloogilise fenomeni tähistatavat väljendatakse tähistaja "söök võõralt laualt" abil. Artiklis visandatakse parasitismi semiootika lähtekohad, toetudes Jakob von Uexkülli omailma ning Maturana ja Varela struktuurse sidustuse mõistetele, samuti rõhutades koevolutsioonilise protsessi fenomeni koosluste ökoloogia aspektis. Antakse kirjanduslike ja meditsiiniliste näidete lühiülevaade XVII saj. Inglismaa ajaloost, kus paljud kirjutised mainivad parasitismi tolleaegses religioosses praktikas (näit. armulaud) ja poliitikas (näit. suhe õukonna ja monarhi vahel). Võimalik on mõista ka keele ja bioloogia omavahelist suhet kui "parasiitlust". 